\title{
The Factors Affecting Luxury Brand Purchase Intention in Terms of Rational and Emotional Impact in Qatar
}

Mudallala Muhammed MOUSA iDa

aIstanbul Aydin University, Department of Business Administration, İstanbul, Turkey. mudallala9@hotmail.com

\begin{tabular}{|c|c|}
\hline ARTICLE INFO & ABSTRACT \\
\hline $\begin{array}{l}\text { Keywords: } \\
\text { Luxury Brands } \\
\text { Purchase Intention } \\
\text { Emotional Effect } \\
\text { Rational Effect }\end{array}$ & $\begin{array}{l}\text { Purpose - The study aimed to understand the factors that influence consuming international luxury } \\
\text { brands in Qatar with considering } 3 \text { factors of the independent variables are affected by emotional } \\
\text { decision based to purchase luxury brands (The Need of Uniqueness, Hedonism, and } \\
\text { Conspicuousness) and } 2 \text { other factors are affected by rational decision based ( Quality and } \\
\text { Materialism). For that, the research is a causal study. }\end{array}$ \\
\hline $\begin{array}{l}\text { Received } 21 \text { September } 2018 \\
\text { Revised } 2 \text { July } 2019 \\
\text { Accepted } 5 \text { July } 2019\end{array}$ & $\begin{array}{l}\text { Design/methodology/approach - The research was a quantitative method based. } 251 \text { questioners } \\
\text { were collected. The study conducted exploratory factor analysis for the need for uniqueness due to } \\
\text { the } 3 \text { different sub-dimensions that it has, confirmatory factor analysis for all of the variables to } \\
\text { measure the validity and reliability of the model and multiple regression analysis to test the } \\
\text { hypothesis. }\end{array}$ \\
\hline \multirow[t]{2}{*}{$\begin{array}{l}\text { Article Classification: } \\
\text { Research Article }\end{array}$} & $\begin{array}{l}\text { Findings - The research findings indicate that the need for uniqueness (Avoidance of Similarity and } \\
\text { Creative Choice) have a significant impact on consuming luxury brands, while the third sub- } \\
\text { dimension, the unpopular choice wasn't tested due to analyzing the issue. As well, hedonism, } \\
\text { conspicuousness, and quality presented the same result. However, materialism didn't show a } \\
\text { statistically significant impact on consumer purchase intention of buying luxury brands. }\end{array}$ \\
\hline & $\begin{array}{l}\text { Discussion - The study can be beneficial for marketerrs to understand the consumer intention to } \\
\text { have luxury brands goods and increase their sales. The study as well contributes to luxury brands } \\
\text { literature to give new insight into what affect consumer's buying intention of luxury brands in. As } \\
\text { this new phenomenon has speared among the country and the studies are still limited to it. }\end{array}$ \\
\hline
\end{tabular}

\section{Introduction}

Even though, the world witnessed an increase in the luxury brands consumption, the researches in this domain still limited, especially in the middle east as most of the studies tended toward European countries and United estates (Chipp et al., 2011). Additionally, the researches concerned and aimed to study the luxury related matter in Qatar are limited as well (Farrag, 2017). As the consumption of luxury brands is increasing year after year in Qatar. This study concerns to study the emotional and rational motivations that lead consumers in Qatar to be attracted to International luxury brands. During the purchasing decision making, Consumers, generally, are stimulated either by their feelings or by their way of thinking. There are several studies that refer to how the consumers perceive the brand to a cognitive or an emotional base (Keller, 2001; Yoo et al., 2000; Morris et al., 2002). However, according to this study, the emotional effect includes the need for uniqueness, hedonism, and conspicuousness. While the rational effect has perceived quality and materialism. This research will study the effect of the 5 dimensions on luxury purchase intention. How these factors are connected to consumer intention of buying a Fendi dress, Gucci Sunglasses or Louis Vuitton handbag etc? this is what the study is going to reveal by studying the motivations behind repeating the same experience of purchasing luxury brands. The scholars and the practitioners as well have found that senses have a strong influence on consumer purchasing the brand (Franzak et al., 2014 ). Also, (Bowden, 2009) studied the customer engagement to determine the relationship between the consumer and the brand and found that marketers should put a high emphasis on the consumer's emotions if they want to build a strong correlation between the consumer and the brand. For that, understanding the nature of consumer needs and know whether it is a need for uniqueness, hedonism or conspicuousness is a significant issue. On the other hand, the research carries the cognitive effects, Fishbein and Middlestadt implied that the consumer attitude refers to a practical belief, which is a kind of cognitive way, and based on those beliefs marketers could recognize the purchase intention of the consumer (Fishbein \& Middlestadt, 1995). As quality and

\section{Suggested Citation:}

Mousa, M. M. (2019). The Factors Affecting Luxury Brand Purchase Intention in Terms of Rational and Emotional Impact in Qatar, Journal of Business Research-Turk, 11 (3), 2191-2204. 
materialism could be the needs that satisfy the consumer practical mindset (Fiore \& Kim, 2007). Nevertheless, there is a gap between the increasing consumption of international luxury brands in Qatar and realizing the hidden incentives that stand behind this phenomena. Therefore, this study is an attempt to reduces the gap between them. Understanding the luxury brands domain still ambiguous and underinvestigation (Berthon et al., 2009). For that, there is a need of studying this area as the scholars' knowledge about luxury brands still limited which make them unable to popularize the consumption operations (Arnould \& Thompson, 2005; Lye et al., 2005). With the increasing demand for luxury brands and the growing of its market, many scholars are interested in studying the reasons behind this growth. However, moving to middle east specifically to Gulf region as it is considered a good environment to study the motivations of buying luxury brands since it is a very popular phenomenon these days, particularly, in Qatar which is in 2013 was ranked as the fastest growing luxury market in the world (Zaryouni, 2013). So the aim of this study is to give an up-to-date insight related to luxury brands consuming in Qatar by determining the factors that affect consumer intention to purchase luxury brands and understand the nature of these variables among Qatari luxurious consumers. As the luxury markets are growing rapidly in the Gulf region specifically in Qatar. Luxury brands marketing is growing very fast in Qatar and the competition is very high. Therefore, this study is essential to luxury brands marketers. The marketers of this segment have to understand what affects the consumer perception of buying luxury brands to motivate these factors and provide customer needs.

\subsection{Research Objectives}

The objectives of the study represent the research questions that the study is going to answer by investigating what stimulates consumers in Qatar to purchase luxury brands. The study has 3 main objectives:

- Objective 1: Is the consumer's purchase intention of luxury brands in Qatar affected by the emotional effects (The Need for Uniqueness, Conspicuousness, and Hedonism)?

- Objective 2: Is the consumer's purchase intention of luxury brands in Qatar affected by the rational effects (Quality and Materialism)?

- Objective 3: What are the motivations that influence consumers purchase intention in Qatar to buy luxury brands?

\section{Conceptual Framework}

(Deli-Gray et al., 2010) in their research came out with that consumers in the $21^{\text {st }}$ century build the purchase decision making not just based on cognitive reasons but it could be emitted from the consumer's sensation. The hedonic products are emulating the feelings and the purpose of purchasing such goods is to have fun or because of fantasy and the pleasure the products bring while the functional products are contacting the logic and the goal of consuming such products is instrumental (Holbrook \& Hirschman, 1982). However, this research studied the effect of 5 dimensions (independent variables) which are the need for uniqueness, hedonism, and conspicuousness (emotional effect) and the other 2 are quality and materialism (rational effect) on the consumer purchase intention of luxury brands (dependent variable).

\subsection{Purchase Intention (Dependent Variable)}

This study emphasized the concern about purchase intention of luxury brands due to its wide application as well to the positive impact that purchases intention has on consumer decision making to buy the goods (Pierre et al., 2005; Schlosser et al., 2006). Purchase intention is a reflection of consumer satisfaction. The definition of the purchase intention clearly manifests this idea by considering it as a promise the consumer gives to him/herself to buy the same product when shopping again (Tariq et al., 2013) . The motivations for consuming luxury brands is what increases the consumer intention of repeating the same experience (Husic $\&$ Cicic, 2009). However, considering the purchase intention in the context of luxury brands gives a concept of how much they are connected. The tight connection of purchase intention and why consumers buy luxury brands is supported by many studies (e.g. Yoo \& Lee, 2009; Dubois \& Paternault, 1995). According to this study, the purchase intention of buying luxury brands in Qatar is affected and stimulated by 5 dimensions ( The Need for Uniqueness, Hedonism, Conspicuousness, Quality, and Materialism). These motivations represented the factors that affect customers in Qatar and increase consumer intention to buy international 
luxury brands. Nevertheless, this study is going to prove the correctness of this connection by conducting an empirical study.

\section{The Five Dimensions (Independent Variables)}

\subsection{The Need for Uniqueness}

Uniqueness is the pursuing of goods that consumers could use to differentiate themselves from others, another purpose of these goods is to impress others (Tian et al., 2001). Those kinds of customers who have a need for uniqueness their need comes from 3 basic types of uniqueness (knight \& Kim, 2007).

1. Avoidance of similarity

2. Unpopular choice counter-conformity

3. Creative choice counter-conformity

\section{Avoidance of similarity}

The consumers belong to avoiding similarity category may discontinue using the good they have, if somebody else owned a similar one. These consumers differentiate themselves by buying products that can't be owned by everyone. For that, they are watching people possessions around them in order to avoid the like acquisition (Tian et al., 2001).

\section{Unpopular choice counter-conformity}

Consumers who belong to unpopular choice counter-conformity are less to concern about social acceptance of their purchasing behavior (Bhadur \& Stanforth, 2016). They tend to force their taste amongst the community which may don't harmonize with their norms and customs. Nevertheless, this kind of consumers risk the society disapproval just to be unique regardless of this uniqueness is positive or negative. Even though the products may not be accepted at the first show, but later on in the future, they may be accepted by the social surroundings (Tian et al., 2001). Consumers here try to rebel against the normality to reach the up normal of uniqueness. Interestingly, the result of unpopular choice counter-conformity behavior is increasing the consumer self-image (knight \& Kim, 2007).

\section{Creative choice counter-conformity}

Consumers whose consuming behavior is derived from creative choice counter-conformity are seeking uniqueness by differentiating themselves from others through creating a unique and creative personal style. This style is usually represented by the material display and to reach the goal of such behavior, the purchase of materials should be original and distinctive (Tian et al., 2001) like luxury brands. However, even the consumers want to distinguish themselves from others, but also they want their new idea to be a good one in their social surroundings (Bhadur \& Stanforth, 2016; Tian et al., 2001). Therefore, the luxury brands that have innovative characteristics like exclusivity and prestige are targeted to this type of consumers (knight \& Kim, 2007). Consuming action which is affected by this type of consumer behavior reflect the idea of Creative choice counter-conformity. In a study, they have argued that the more unique the product is, the more value it has (Tian et al., 2001). Nevertheless, this study has hypothesized all 3 types of uniqueness in order to understand which one influence the purchase intention of luxury brands.

$\mathrm{H}_{1 . a:}$ Avoidance of similarity has a positive and significant influence on the purchase intention of luxury brands in Qatar.

H1.b: Unpopular choice has a positive and significant influence on the purchase intention of luxury brands in Qatar.

$\mathrm{H}_{1 . c:}$ Creative choice has a positive and significant influence on the purchase intention of luxury brands in Qatar.

\subsection{Hedonism}

Hedonism constructs an essential foundation in influencing consumer desire to purchase luxury brands as it was clear in the previous studies (Wiedmann et al., 2007; Vigneron \& Johnson, 2004; Shukla, 2012). Therefore, the influence of hedonism aspects on consumer behavior contributes greatly to the scientific 
researches in marketing review (Kazakeviciute \& Banyte, 2012). Hedonism consumption is the consumption that is stimulated by sentimental effects and connected to the feelings the consumer get from using the products, this definition was established by (Holbrook \& Hirschman, 1982). (Wiedmann et al., 2007) pointed out that luxury products could carry intangible advantages such as sensory pleasure or aesthetic aspects. However, (Martínez-López et al., 2016) return the hedonic motivations to 11 reasons which are exploration and curiosity. According to Silvia (2012), the curiosity of the consumer is stimulated by internal motivation which encourages the consumer to explore and learn more about the products or services. Also trying new emotions and entertainment (Kim et al., 2010) or adventure (Arnold \& Reynolds, 2003). Visual attraction is stimulating consumer by the physical attractiveness of the product (Holbrook, 1994). Escaping reality also is a reason for hedonism (Babin et al., 1994). Hang out could also push hedonist to go shopping. (Seo \& Green, 2008). Hedonist also shops for relaxation. Role shopping refers to consumer pleasure which is motivated by purchasing goods for others. Also Intrinsic enjoyment, Self-expression and Stay involved with a product/service trigger hedonist to go shopping. For all these reasons, hedonists intend to consume luxury brands as a reward to satisfy an inner need for pleasure (Vigneron \& Johnson, 2004). For that, the perceived hedonism of luxurious consuming is completely emotional decision-based for the joy lover.

$\mathrm{H}_{2}$ : Hedonism has a positive and significant influence on the purchase intention of luxury brands in Qatar.

\subsection{Conspicuous Consumption Theory}

Scholars defined the conspicuous consumption as an ostentatious show of wealthy people in order to display their affluence to keep their prestige or social position or even use this kind of consumption to gain a new social status (Vigneron \& Johnson, 1999; Truong et al., 2010). Nevertheless, Veblen pointed out that people consciously display their richness by the goods they buy. Furthermore, the theory stated that people try to emulate the upper social class in purchasing goods (Truong, McColl \& Kitchen 2010). The theory of conspicuous consumption was established by Veblen in 1899, that's what some studies stated (Visser, 2015), but that's not the real case. However, according to (Leibenstein 1950) even the conspicuousness theory gained its popularity because of Vablen, there were earlier studies about it. John Rae in 1834 wrote about the conspicuous consumption in regarding the fashion and other related subjects (Leibenstein 1950). And according to the same author, the conspicuous idea existed before this time as it was mentioned in Roman poet Horace. So, thinking about consuming products conspicuously not a recent issue nor a new phenomenon. Nevertheless, the intention of purchasing conspicuous products has a substantial influence in shaping the consumer preferences, especially, if the product is to be exposed in public (Vigneron \& Johnson 2004; Wiedmann, Hennigs \& Siebels 2009; Shukla 2012; Braun \& Wicklund 1989; Hong \& Zinkhan 1995). However, what gives the conspicuous good a value is its job of showing how much the owner is rich (Shukla, 2012). Using Luxury brands are the perfect tool to explain such a thing without using a single word, as they speak the status.

$\mathrm{H}_{3}$ : Conspicuousness has a positive and significant influence on the purchase intention of luxury brands in Qatar.

\subsection{Quality}

The researches in luxury brands had emphasized the importance of quality as it plays a leading role in the perception of luxury (Quelch, 1987). In marketing, literature quality is referred to instrumental aspects (Fiore \& Kim, 2007)which mean it is affected by rational influence. However, the area related to quality is broad. Consequently, its definition varies from specialist to another and from product to another (Abu Hassan \& Shaharudin, 2011). According to (Sebastianelli \& Tamimi, 2002) there is no identified definition of quality globally. But in the attempt of defining the construct of quality, researches established alternative definitions based on five tactics:

1. The transcendent approach: the meaning of quality according to this approach is embodied in instinctive excellence. This what's quality meant according to philosophers.

2. The product-based approach: quality here means the manipulating in the ingredients or the attributes of the product resulting in a difference in the product quality (Garvin, 1984; Abbott, 1955). This is how economists look at quality.

3. The user-based approach: quality could be identified according to which degree the product or service 
satisfies the consumer (Sebastianelli \& Tamimi, 2002). This is the quality according to marketers. For example, if the product met the consumer's expectation or exceeded them, then the product has a highquality level and vice versa (Abu Hassan \& Shaharudin, 2011).

4. The manufacturing-based approach: the quality here refers to which extend the products meet a creation specification or standards. This how the production and operation department identify the quality.

5. The value-based approach: the quality refers to the product performance with achieving a reasonable price. This approach joins the product based approach in regard to the economist perspective.

However, in general meaning of quality, quality meets the meaning of luxury brands that some consumers believe quality means luxury brands and luxury brands mean quality according to Dubois et al (2001). That's usually returned to the production process of the luxury brands which is hand-made as this way provide the product with superior quality and performance (Quelch, 1987; Vigneron \& Johnson, 2004). This is another reason why consumer perceived the luxury brand value as a superior quality which makes the connection between the quality and the luxury product very tight. As a result, the consumer perceived the quality value of luxurious goods as extraordinary. According to (Brunso et al., 2005) Quality can be analyzed according to two various perspectives:

1. The perceived quality which is the consumer judgment about product attributes as a whole and its excellence (Zeithaml, 1988).

2. The objective quality which is based on the measuring of the quality according to the internal and external aspects of the products (Abu Hassan \& Shaharudin, 2011). According to that the hypothesis supposed that:

$\mathrm{H}_{4}$ : Quality has a positive and significant influence on purchase intention of luxury brands in Qatar.

\subsection{Materialism}

The originality of materialism return to a philosophical concept which says nothing exists but matter and its movement. Materialism usually refers to the deduction of interest to objective needs with ignoring the subjective needs (Richins \& Dawson, 1992). It has been considered the materialism as a life curriculum, belief or interest which based completely on materials as well as it could adopt the notion of gaining and spending (Richins \& Dawson, 1992). However, Materialism also represents the relationship that connects the consumer with her/his possessions and to which extent s/he is related to them (Belk, 1995). Thus, the possessions and gaining them are considered the essence of understanding the meaning of materialism $(\mathrm{Du}$ Bois, 1955). Accordingly, the most important thing for Materialists is how to acquisition more and more possessions. Fore that they give all their energy and resources to purchase materials (Segev et al., 2015), even if they have to borrow money from others to get what they want. Materialism is influenced by the purpose consumers wish from their possessions and the type of goods that fulfill their needs (Chan et al., 2015). As the largest part of the luxury brands segmentation in the market goes to materialistic consumers (Chan et al., 2015), we can figure out the type of products materialists desire, according to (Wiedmann et al., 2009) materialism is one of the most essential factors that impact the consumers attitude toward purchasing luxury brands. However, even the concept of materialism is related to consumer behavior caught the attention of researchers since the late 1950s (Wiedmann et al., 2007), but they still didn't refer it to a single definition (Richins \& Dawson, 1992), as they comprehend it from different angles (Wiedmann et al., 2007). Therefore, the study supposed:

$\mathrm{H}_{5}$ : Materialism has a positive and significant influence on the purchase intention of luxury brands in Qatar. The proposed model that was developed based on the previous literature review is shown in figure 1 . 
M. M. Mousa 11/3 (2019) 2191-2204

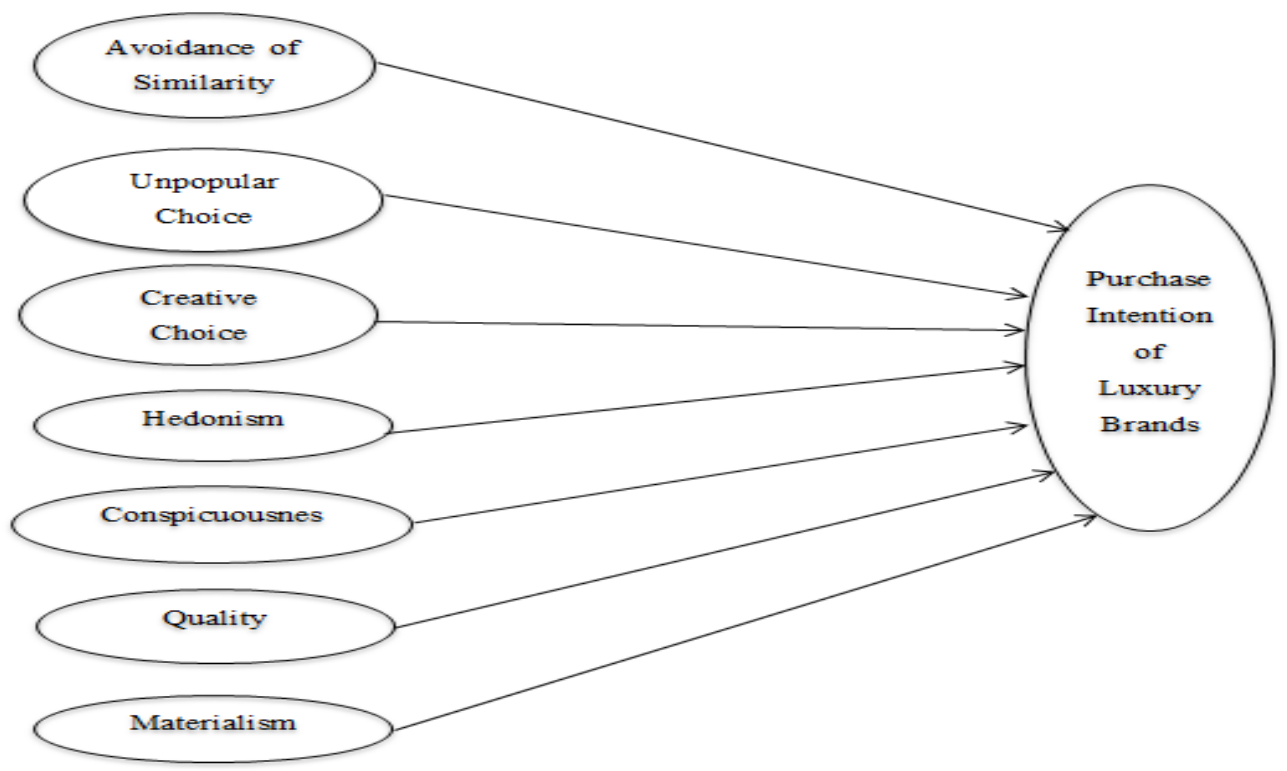

Figure 1: The proposed model

\section{Methodology}

This research is a causal study as it meant to investigate the motivations of luxury brands consuming. According to this study, the purchase intention of buying luxury brands in Qatar is affected and stimulated by 5 dimensions (The Need for Uniqueness, Hedonism, Conspicuousness, Quality, and Materialism). The study is a quantitative method based and its instrument was survey. Since the sample size between 30 and 500 is convenient to many researches, this study adopted 251 responses to conduct the research. The questionnaires were collected via online from individuals who concern about and purchase luxury brands in Qatar. The convenient sampling method which is non-probability was used to collect the data. The questionnaire contained items of Likert scale. This scale is an interval scale which is based on five anchors explains to what extent the respondent agree with the scale item. However, they consist of strongly disagree, disagree, neutral, agree, and strongly agree (Sekaran \& Bougie, 2016). Table 1.1 represents the scales used in the study. 
M. M. Mousa 11/3 (2019) 2191-2204

Table 1.1: The Summary of Measurement Scale

\begin{tabular}{|c|c|c|}
\hline Variable & Measurement & Author \\
\hline Uniqueness & $\begin{array}{l}\text { Avoidance of similarity } \\
\text { I stop wearing fashions when they become popular with the } \\
\text { general public. } \\
\text { I dislike brands bought by everyone. } \\
\text { When a clothing brand becomes too popular, I wear it less. } \\
\text { Unpopular choice } \\
\text { I look for one-of-a-kind products to create my own style } \\
\text { The things that I buy shape a more unusual personal image } \\
\text { I buy unusual brands to create a more distinctive } \\
\text { personal image } \\
\text { Creative choice } \\
\text { I often combine possessions in such a way that I create } \\
\text { a personal image that cannot be duplicated. } \\
\text { I often try to find a more interesting version of run-of-the- } \\
\text { mill products because I enjoy being original. } \\
\text { I actively seek to develop my personal uniqueness by buying } \\
\text { special products or brands. } \\
\text { Having an eye for products that are interesting and unusual } \\
\text { assists me in establishing a distinctive image. }\end{array}$ & (knight \& Kim, 2007) \\
\hline Hedonism & $\begin{array}{l}\text { I can enjoy luxury brands entirely on my own terms no matter } \\
\text { what others may feel about them } \\
\text { Buying things gives me a lot of pleasure } \\
\text { On the whole, I may regard luxury brands as gifts I buy for } \\
\text { treating myself } \\
\text { Purchasing luxury brands can be seen as giving me gifts to } \\
\text { celebrate an occasion that I believe significant to me }\end{array}$ & (Jiang \& Shan, 2018) \\
\hline Consciousness & $\begin{array}{l}\text { Product prestige is my major reason for buying a luxury } \\
\text { brand } \\
\text { It is important for me that the luxury brand I buy } \\
\text { improves my image The luxury brand I purchase must } \\
\text { be a status symbol }\end{array}$ & (Truong, 2010) \\
\hline Quality & $\begin{array}{l}\text { Luxury brands have consistent quality } \\
\text { Luxury brands have rich workmanship } \\
\text { Luxury brands last a long time }\end{array}$ & (Hennigs et al., 2013) \\
\hline Materialism & $\begin{array}{l}\text { My life would be better if I owned certain things I don't have. } \\
\text { I'd be happier if I could afford to buy more things. } \\
\text { It sometimes bothers me quite a bit that I can't afford to buy all } \\
\text { the things I'd like. } \\
\text { I have all the things I really need to enjoy life }\end{array}$ & $\begin{array}{l}\text { (Wiedmann et al., } \\
\text { 2009) }\end{array}$ \\
\hline $\begin{array}{l}\text { Purchase } \\
\text { Intention }\end{array}$ & $\begin{array}{l}\text { I have a strong possibility to purchase Luxury Brand X's product } \\
\text { I'm likely to purchase Luxury Brand X's product I have a high } \\
\text { intention to purchase Luxury Brand X's product }\end{array}$ & (Hung et al., 2011) \\
\hline
\end{tabular}




\subsection{Exploratory Factor Analysis}

Exploratory Factor Analysis is a statistical method used to identify the relationship between the variables. EFA in this study is used to classify the observed variables (10 questions) of the need for uniqueness according to the appropriate latent variable (Field, 2005). The scales should be correlated in order to measure the same construct and uncorrelated items should be deleted. However, the problem in EFA of this study was in Q9 that belongs to the unpopular choice variable. The question appeared in the pattern matrix under 2 factors. So the researcher had to remove it to solve that. After repeating the analysis the same problem appeared with Q8 which belongs as well to the same variable. For that, the researcher had to delete it. After removing 2 questions of the unpopular choice variable, the grouping issue has been solved but another related problem has appeared. In order to be able to conduct the CFA, each factor must have at least 2 items (Klein, 2011). But as the unpopular choice variable has just 3 items and 2 of them has been deleted, the researcher couldn't use it in CFA and had to remove the whole variable. The final analysis of EFA is explained next. The descriptive data of the sample is represented in table 1.3 by the mean and standard deviation of each item. The KMO result which is .821 indicates that there is a harmony between the variables which means the factor analysis can provide reliable factors. Researchers considered factor loading that is .40 or above have a significance (Hair et al, 1998). Based on table 1.3 the factor loading ranged from .622 to .803 which means all of the factors achieved their threshold. Based on EFA results the need for uniqueness factors are ready to conduct the CFA.

Table 1.2: EFA Results

\begin{tabular}{|llllllll|}
\hline \multirow{2}{*}{$\begin{array}{l}\text { Factor } \\
\text { Avoidance of }\end{array}$} & Question & Mean & $\begin{array}{l}\text { Std. } \\
\text { Deviation }\end{array}$ & KMO & Variance & Factor Loading & Analysis N \\
& & 2.61 & 1.183 & .821 & 42.427 & .788 & 246 \\
& Q5 & 2.51 & 1.128 & & & .728 & 246 \\
Creative & Q6 & 2.63 & 1.156 & & & .747 & 246 \\
Choice & Q10 & 2.31 & 1.023 & & 13.196 & .622 & 246 \\
& Q11 & 2.36 & 1.051 & & & .751 & 246 \\
& Q12 & 2.42 & 1.161 & & & .740 & 246 \\
& Q13 & 2.30 & 1.114 & & & .803 & 246 \\
\hline
\end{tabular}

\subsection{Confirmatory Factor Analysis}

The study used CFA to measure validity and reliability. Validity and reliability complete each other. As validity is meant to measure the accuracy of the scales used in the study. Reliability is meant to measure consistency and steadiness (Smith and Albaum, 2005). In this study, one type of reliability has been conducted which is composite reliability (CR $>0.7)$ and 2 types of validity. Convergent validity (AVE $>0.5)$ and discriminant validity(MSV < AVE and AVE > inter-construct correlations) (Hair et al., 2010).The last version of validity and reliability tests after removing Q14 and Q27 shown in table 5.3. According to this table, CR ( Composite Reliability) values are ranged from $0.784-0.855$ which means all the variables were > 0.7. Therefore, all the variables in this study are reliable. The most reliable factor which achieved the highest $\mathrm{CR}$ value is conspicuousness as its value is 0.855 while the least reliable one is luxury brands purchase intention as its value is 0.784. However, AVE (Average Variance Extracted) as well exceeded the required threshold in all values. As AVE of all variables is $>0.5$ which are ranged between 0.540 and 0.663 . In AVE the most variable achieved the convergent validity is conspicuousness at 0.663 while the least one was a creative choice at 0.540 . Moving to discriminant validity, to perform this type of validity MSV should be less than AVE and as it's represented in table 3.5 this condition has been accomplished. The second condition is that AVE must be more than inter-construct correlations. According to the table quality value which is $0.746>$ 0.557 . Luxury brands purchase intention value is $0.740>0.548$. Avoidance of similarity value is 0.756 is more than 0.571 . Creative choice value is $0.735>0.540$. Hedonism value is $0.746>0.557$. Conspicuousness value is $0.814>0.663$. Materialism value is $0.761>0.579$. According to these results, the second condition of discriminant validity has been achieved. The outcomes of CFA is shown in table 1.4. 
Table 1.3: The Result of Validity and Reliability Tests

\begin{tabular}{|l|l|l|l|l|l|l|l|l|l|l|l|}
\hline & CR & AVE & MSV & MaxR(H) & QLTY & LBRI & AOS & CC & HEDO & CONS & MTRL \\
\hline QLTY & 0.790 & 0.557 & 0.077 & 0.791 & $\mathbf{0 . 7 4 6}$ & & & & & & \\
\hline LBRI & 0.784 & 0.548 & 0.489 & 0.789 & 0.278 & $\mathbf{0 . 7 4 0}$ & & & & & \\
\hline AOS & 0.799 & 0.571 & 0.391 & 0.804 & 0.083 & 0.541 & $\mathbf{0 . 7 5 6}$ & & & & \\
\hline CC & 0.824 & 0.540 & 0.537 & 0.830 & 0.156 & 0.636 & 0.522 & $\mathbf{0 . 7 3 5}$ & & & \\
\hline HEDO & 0.789 & 0.557 & 0.537 & 0.803 & 0.225 & 0.699 & 0.491 & 0.733 & $\mathbf{0 . 7 4 6}$ & & \\
\hline CONS & 0.855 & 0.663 & 0.413 & 0.858 & 0.217 & 0.643 & 0.625 & 0.617 & 0.629 & $\mathbf{0 . 8 1 4}$ & \\
\hline MTRL & 0.803 & 0.579 & 0.397 & 0.835 & 0.179 & 0.570 & 0.484 & 0.593 & 0.625 & 0.630 & $\mathbf{0 . 7 6 1}$ \\
\hline
\end{tabular}

\section{Findings}

The outcome of multiple regression analysis is represented in table 1.5 according to multicollinearity test, the tolerance value should be more than 0.1 and VIF $<3$ according to (Gaskin, 2016). all the independent variables have tolerance values more than .1 and VIF less than 3. also R square has represented .435 which is $43 \%$ then the result is good and acceptable. additionally, sig. $=.000$. As this value is less than 0.05 then it is accepted. While the F-value range from 0 to positive infinity. And as it is shown in table F- Value is 30.613. Tvalue equal to 2.188 and $p$-value is $.030(p<0.05)$ which means there is a significant correlation between avoidance of similarity and LBRI. while B value is .115 which means that avoidance of similarity has $11 \%$ effect on the purchase intention of luxury brands. Since the $t$-value $=2.727$ and $p$-value $.007(p<0.05)$ then there is a significant correlation between the independent and the dependent variable as well it is a positive one. That means the hypothesis is correct and it is accepted. And as B is .132 that means creative choice has a $13 \%$ impact on consumer intention of buying luxury brands. The values tell that $t$ - value is 3.657 and $p$-value is $.000(p<0.05)$. As a result, there is a significant correlation between hedonism and the luxury brands purchase intention as well it is a positive one. B value is .239 which mean hedonism influence the intention of consumer's to buy luxury brands by $23 \%$. Also, in Conspicuousness t-value is 3.000 and p-value is .003 $(\mathrm{p}<0.05)$. As $B$ value is .174 that means conspicuousness has $17 \%$ impact on luxury purchase intention. In quality t-value is 2.263 and p-value is .025 then what is suggested is true and quality affects the intention of purchasing luxury brands positively and significantly. Table 1.5 also represents B as .149 which means quality has $14 \%$ of affecting the consumer purchase intention of luxury brands. Quality took the third place of variables that have an influence on luxury brands purchase intention. In materialism that $\mathrm{t}$-value is .829, the p-value is .408 ( it is more than 0.05 ). These values show a reverse of the hypothesis suggestion since the values haven't met the needed requirement to accept the hypothesis.

Table 1.1: Multiple Regression Results

\begin{tabular}{|c|c|c|c|c|c|c|c|c|c|}
\hline & B & $\mathrm{T}$ & Sig. & $\mathrm{F}$ & $\mathrm{P}$ & $\mathrm{R}$ & $\mathrm{R}^{2}$ & Tolerance & VIF \\
\hline (Constant) & .678 & 1.293 & .197 & 30.613 & .000 & 0.659 & 0.435 & & \\
\hline $\begin{array}{l}\text { Avoidance of } \\
\text { similarity }\end{array}$ & .115 & 2.188 & .030 & & & & & .687 & 1.456 \\
\hline Creative Choice & .132 & 2.727 & .007 & & & & & .560 & 1.785 \\
\hline Conspicuousness & .174 & 3.000 & .003 & & & & & .533 & 1.875 \\
\hline Quality & .149 & 2.263 & .025 & & & & & .953 & 1.050 \\
\hline Hedonism & .239 & 3.657 & .000 & & & & & .541 & 1.847 \\
\hline Materialism & .047 & .829 & .408 & & & & & .622 & 1.607 \\
\hline
\end{tabular}


According to the previous analysis, the hypothesis results explained in table 1.6.

Table 1.2: Hypothesis Results

\begin{tabular}{lllll}
\hline H & Relation & \multicolumn{3}{c}{ Status } \\
\hline H1.a & LBRI & $<--$ & AOS & Supported \\
H1.b & LBRI & $<--$ & UNPP & Not Tested \\
H1.c & LBRI & $<--$ & CC & Supported \\
H2 & LBRI & $<---$ & HEDO & Supported \\
H3 & LBRI & $<---$ & CONS & Supported \\
H4 & LBRI & $<---$ & QLTY & Supported \\
H5 & LBRI & $<---$ & MTRL & Rejected \\
\hline
\end{tabular}

\section{Conclusion and Implication}

Striving for a luxurious lifestyle isn't a new aspect. it is an aspect without a beginning and without an ending. Its existing is connected with the human being existing (Brun \& Castelli, 2013). Even though the luxury facets weren't the same all the time, as their aspects evolved over time and differed according to the differentiation in each culture (Barnier et al., 2012). The idea of luxury was born since ancient time and kept growing till these days. the ancient civilization tied luxury goods with the meaning of wealth and power as it represents the exclusiveness (Brun \& Castelli, 2013). However, regardless of all attempts to define the luxury still there is no agreement upon one definition. And the concept of luxury still mysterious even though researchers identified a slight of it according to Dubois (1991) cited in (Barnier et al., 2012). However, with the increasing interest in the luxury field year after year, the researchers became conscious of this gap in their studies and they are trying to establish the core of the luxury nature as it's an essential part of continuing the researches in this field (Barnier et al., 2012). Nevertheless, this study continues what the researchers have established in the luxury brands field. As this work emphasis on 5 factors that motivate the luxury brands consuming in Qatar in terms of rational and emotional effects. The research studied the effect of the need for uniqueness, hedonism, conspicuousness, quality, and materialism on the consumer purchase intention of luxury brands in Qatar. The findings of this research met the objectives of the study. The first objective which asks: Is the consumer's purchase intention of luxury brands in Qatar affected by the emotional effects (The need for uniqueness, conspicuousness, and hedonism)? was met by hypothesis H1.a, H1.b, H1.c, H2, H3. The need for uniqueness was hypothesized by the 3 types of uniqueness. However, 2 of them were tested which are avoidance of similarity hypothesis and Creative choice hypothesis and both of them were supported and showed that they affect the purchase intention of luxury brands positively and significantly. That supports what (Tian et al., 2001) stated, it has been expected that the consumers with a high need for uniqueness tend to engage in product consumption due to a classification purpose rather than experience or joyful. The same work has found that the need for uniqueness could identify how important possessions enhance social differences. However, the unpopular choice hypothesis couldn't be tested due to the analysis issue explained in data analysis chapter. The next dimension of emotional influence which is hedonism as well was supported by the result of the study which showed positivity and significance that hedonism has on the purchase intention of luxury brands consumer. This finding is an extent to (Hagtvedt \& Patrick, 2009) finding that stated the hedonic features of luxury brands enhance consumer evaluation of the brand. The third dimension of emotional effect which shows conspicuousness as an aspect of consuming luxury brands was supported as the result represented a positive and influential impact on consumer's intention to purchase luxury brands. That means the conspicuous consumption which has been connected with luxury goods by using the goods to show off the owner's wealth as well as a show of his/her status economy (Mason, 1998), occupy a space of consumer intention to buy luxury brands and can stimulate the consumer desire to have such brands. On the other hand, Objective 2 which inquire if the consumer's purchase intention of luxury brands in Qatar is affected by the rational effects ( quality and materialism)? was met by $\mathrm{H} 4$ and $\mathrm{H} 5$. The effect of quality on purchase intention of buying luxury brands was supported by the finding of the study. As this result is confirmed with what (Farrag, 2017) said which is that the opinion of the managers of luxury stores, who she had interviewed in Qatar, emphasized that the Qatari consumers used quality as an indicator of their luxury consumption. Nevertheless, even though, some studies stated that Asian countries are more materialistic than European ones ( $\mathrm{Li}$ and Zhang, 2011), but this wasn't the case in Qatar as the findings of this study showed that materialism didn't have a significant impact on the consumer intention of buying luxury brands in Qatar. Even though, the result supports (Farrag, 2017) 
research which conducted research about what affect young consumers in Qatar to purchase luxury brands. (Farrag, 2017) excluded materialism of her study factors based on exploratory research. As she concluded that based on the interviews she conducted with experts materialism doesn't have an effect on consuming luxury brands in Qatar. While the current result of the study counters the finding of another study that concerned to test the relationship of materialism and having the intention of buying luxury brands of fashions among Arab and American. As the findings of the study represented a positive influence of materialism in both samples (Kamal et al., 2013). However, regardless of the contrary, the findings of this study showed that the first dimension of rational effect which is quality has an impact on consumer's purchase intention of luxury brands while the other dimension which is materialism didn't represent an impact on consumer's purchase intention in Qatar.

Finally, based on the findings of the study, it can be concluded that there are 4 dimensions that influence and motivate consumers in Qatar to have an intention to buy luxury brands which are the need for uniqueness ( Avoidance of similarity and creative choice), hedonism, conspicuousness, and quality. In this way, the study fulfills objective number 3 that says What are the motivations that influence consumers purchase intention in Qatar to buy luxury brands?. Based on the study findings consumers in Qatar are mostly affected by hedonism to have the intention of luxury brands consuming then by conspicuousness then by quality after that comes creative choice and the least one has an effect on purchase intention of luxury brands is avoidance of similarity. In the whole, the five dimensions of consuming luxury brands intention are likely to be correlated. Even though consumers may be affected by all of them to purchase the luxury brands, they would tradeoff the less outstanding factor for the more outstanding ones (Vigneron \& Johnson, 2004).

This work could be beneficial for academic purposes plus to the marketers' strategies. For academicians, they can develop other empirical studies based on the findings of the study. For marketers, understanding the phenomena of consuming luxury brands in Qatar help marketers in analyzing the nature of consumer purchasing intention and how they can affect it. Influencing consumer decision making of purchasing the luxury brands positively by marketers can increase the sales which accordingly increase their profits. Therefore, the significance of understanding what influence consumer purchasing choices and how to affect them returns to those reasons. The success of any firm comes from understanding consumer needs and the ability to fulfill those needs. As a way of understanding consumer behavior, many kinds of research have been conducted and they found that the decrease of products supply, increase the consumer desire and brand demand (Verhallen, 1982; Lynn, 1991). It's clear that the limited number of products gives the products high value and make it more desirable than those that are available everywhere and all the time. In addition to that, the rarity of the brands symbolizes the prestige of the consumer as mentioned by (Solomon, 1994). These characteristics meet luxury brands characteristics. Therefore, the findings of this study which indicate how the need for uniqueness, hedonism, conspicuousness, and quality affect the consumer purchase intention positively are important. As marketers can focus on and manipulate these factors to affect the purchase intention of luxury brands.

\section{References}

Abbott, L., 1955. "Quality and competition". New York: Columbia.

Abu Hassan, A. \& Shaharudin, M.R., 2011. "Product Quality Dimensions Ranking: The Preference of National Motorcycle Brand Customers". Voice of Academia, 6(2), pp.31-38.

Arnould, E.J. \& Thompson, C.J., 2005. “Consumer culture theory (CCT): twenty years of research". Journal of Consumer Research, 31, pp.868-882.

Barnier, D., Falcy, \& Valette-Florence, 2012. "Do consumers perceive three levels of luxury? A comparison of accessible, intermediate and inaccessible luxury brands". Journal of Brand Management, 19(7), pp. 623-636.

Belk, R.W., 1995. "Hyper-reality and globalization: culture in the age of Ronald McDonald". Journal of International Consumer Marketing, 8(3/4), pp. 23-37.

Berthon, R., Pitt, L., Parent, M. \& Berthon, J.-P., 2009. “Aesthetics and ephemerality: observing and preserving the luxury brand". California Management Review, 52(1), pp.45-66. 
Bhadur, G. \& Stanforth, N., 2016. "Evaluation of absolute luxury: Effect of cues, consumers' need for uniqueness, product involvement and product knowledge on expected price". Journal of Fashion Marketing and Management: An International Journal, 20(4), pp.471-486.

Bowden, J., 2009. “Customer engagement: a framework for assessing customer-brand relationships: the case of restaurant industry". Journal of Hospitality Marketing and Management, 18, pp.574-596.

Braun, O.L. \& Wicklund, A., 1989. "Psychological Antecedents of Conspicuous Consumption". Journal of Economic Psychology, 10(2), pp.161-186.

Brun, \& Castelli, , 2013. "The nature of luxury: a consumer perspective". International Journal of Retail \& Distribution Management, 41(11/12), pp.823-47.

Brunso, K., Bredahl, L., Grunert, K.G. \& Scholderer, J., 2005. "Consumer perception of the quality of beef resulting from various fattening regimes". Livestock Production Science, 94(1/2), pp.83-93.

Chan, Y., M., C.K. \& Chu, W.C., 2015. "Materialistic consumers who seek unique products: How does their need for status and their effective response facilitate the repurchase intention of luxury goods?" Journal of Retailing and Consumer Services, 27, pp.1-10.

Chipp, K., Kleyn, N. \& Manzi, T., 2011. Catch Up and Keep Up: Relative Deprivation and Conspicuous Consumption in an Emerging Market. Journal of International Consumer Marketing, 23, pp.117 - 134.

Du Bois, C., 1955. "The Dominant Value Profile of American Culture". American Anthropologist, 57 (12), pp. 32-39.

Dubois, B. and Paternault, C., 1995, "Observations - understanding the world of international luxury brands: the dream formula", Journal of Advertising Research, 35(4), pp. 69-76.

Farrag, , 2017. "The young luxury consumer in Qatar". Young Consumers, 18(4), pp.393-407.

Field, A. (2005). Discovering statistics using SPSS. Thousand Oaks, CA: Sage.

Fiore, A.M. \& Kim, J., 2007. "An integrative framework capturing experiential and utilitarian shopping experience". International Journal of Retail \& Distribution Management, 35(6), pp.421-442.

Fishbein, M. \& Middlestadt, S.E., 1995. "Noncognitive Effects on Attitude Formation and Change: Fact or Artifact?". Journal of Consumer Psychology, 21(4), pp.181-202.

Franzak, F., Makarem, \& Jae, , 2014. "Design benefits, emotional responses, and brand engagement". Journal of Product \& Brand Management, 23(1), pp.16-23.

Garvin, D.A., 1984. "What does product quality really mean?" Sloan Management Review , pp.25-43.

Gaskin, J., 2016. Structural Equation Modeling. Available at: http://statwiki.kolobkreations.com/index.php?title=Structural_Equation_Modeling. [Accessed 20 January 2019].

Hagtvedt, H. and Patrick, V.M., 2009, "The broad embrace of luxury: hedonic potential as driver of brand extendibility", Journal of Consumer Psychology, Vol. 19, pp. 609-618.

Hair, JF, Anderson, RE, Tatham, R.L., \& Black, W 1998, Multivariate Data Analysis. Fifth Edition. Upper Saddle River, NJ: Prentice-Hall.

Hennigs, N., Wiedmann, K.-P., Behrens, S. \& Klarmann, C., 2013. "Unleashing the power of luxury: Antecedents of luxury brand perception and effects on luxury brand strength". Journal of Brand Management, 20(8), pp.705-715.

Holbrook, M.B. (1994) 'The nature of customer value: an axiology of services in the consumption experience', Service Quality: New Directions in Theory and Practice, pp.21-71.

Hong, J.W. \& Zinkhan, M., 1995. "Self-Concept and Advertising Effectiveness: The Influence of Congruency, Conspicuousness, and Response Mode". Psychology and Marketing, 12(1), pp.53-77. 
Hung, K.-p. et al., 2011. "Antecedents of luxury brand purchase intention". Journal of Product \& Brand Management, 20(6), pp.457-467.

Jiang, L., \& Shan, J., 2018. "Heterogeneity of luxury value perception: a generational comparison in China". International Marketing Review, 35(3), pp.458-474.

Kamal, S., Chu, S.C. and Pedram, M. (2013), "Materialism, attitudes, and social media usage and their impact on purchase intention of luxury fashion goods among American and Arab young generations", Journal of Interactive Advertising, Vol. 13 No. 1, pp. 27-40.

Keller, K.L., 2001. “Building customer-based brand equity: creating brand resonance requires carefully sequenced brand-building efforts". Marketing Management, 10(2), p.Marketing Management.

Kim, J.U., Kim, W.J. \& Park, S.C., 2010. "Consumer perceptions on web advertisements and motivation factors to purchase in the online shopping". Computers in Human Behavior, 26(5), pp.1208-22.

Klein, R. B., 2011. Principles and Practice of Structural Equation Modeling. 3rd ed. s.1.: The Guilford Press.

Knight, D.K. \& Kim, Y., 2007. "Japanese consumers' need for uniqueness: Effects on brand perceptions and purchase intention". Journal of Fashion Marketing and Management: An International Journal, 11(2), pp.270-80.

Leibenstein, H, 1950. "Bandwagon, Snob, and Veblen Effects in the Theory of Consumers' Demand". Quarterly Journal of Economics, 64, pp. 183-207.

Li, L.\& Zhang, J., 2011, "Materialism and conspicuous consumption in China: a cross-cultural examination", International Journal of Consumer Studies, Vol. 35 No. 1, pp. 17-25.

Lye, A., Shao, W., Rundle-Thiele, S. \& Fausnaugh, C., 2005. “Decision waves: consumer decisions in today's complex world". European Journal of Marketing, 39(1/2), pp.216-30.

Martínez-López, F., Pla-García,C. , Gázquez-Abad, J.C. \& Rodríguez-Ardura,I. , 2016. "Hedonic motivations in online consumption behaviour". Int. J. Business Environment, 8(2), pp.121-51.

Mason, R., 1998. The economics of conspicuous consumption: Theory and thought since 1700. Cheltenham, UK \& Northampton: MA: Edward Elgar.

Morris, J.D., Woo, , Geason, J.A. \& Kim, J., 2002. “The power of affect: predicting intention”. Journal of Advertising Research, 43(3), pp.7-17.

Pierre, C., Morwitz, V.G. and Reinartz, W.J. (2005), “Do intentions really predict behavior? Self-generated validity effects in survey research", Journal of Marketing, 69 (2), pp. 1-14.

Quelch, J.A., 1987. "Marketing the premium product". Business Horizons, 30(3), pp.38-45.

Richins, M.L. \& Dawson, S., 1992. "A Consumer Values Orientation for Materialism and Its Measurement". Journal of Consumer Research, 19(3), pp.303-316.

Schlosser, A.E., White, T.B. and Lloyd, S.M. (2006), "Converting web site visitors into buyers: how web site investment increases consumer trusting beliefs and online purchase intentions", Journal of Marketing, 70(13), pp. 3-248.

Sebastianelli,R., \& Tamimi,N. , 2002. "How product quality dimensions relate to defining quality". International Journal of Quality \& Reliability Management, 19(4), pp.442-53.

Segev,S., Shoham,A., \& Gavish,Y. , 2015. "A closer look into the materialism construct: the antecedents and consequences of materialism and its three facets". Journal of Consumer Marketing, 32(2), pp.85-98.

Sekaran, U. \& Bougie, R., 2016. "Research Methods for Business: a skill-building approach". 7th ed. United Kingdom: John Wiley \& Sons Ltd.

Shukla, P., 2012. "The influence of value perceptions on luxury purchase intentions in developed and emerging markets". International Marketing Review, 29(6), pp.574-596. 
M. M. Mousa 11/3 (2019) 2191-2204

Smith, S.M. \& Albaum, G.S. (2005). Fundamentals of Marketing Research. s.l.:Sage.

Solomon, Michael R. (1994), Consumer Behavior, (2nd ed.), Boston, MA.: Allyn and Bacon.

Tariq, M.I., Nawaz, R., Nawaz, M.M. \& Butt, H.A., 2013. "Customer Perceptions about Branding and Purchase Intention:A Study of FMCG in an Emerging Market". Journal of Basic and Applied Scientific Research, 3(2), pp.340-347.

Tian, T., Bearden, W.O. \& Hunter, G.L., 2001. “Consumers' need for uniqueness: scale development and validation". Journal of Consumer Research, Vol. 28(2), pp.50-66.

Truong, , McColl, \& Kitchen, J., 2010. "Uncovering the relationships between aspirations and luxury brand preference". Journal of Product \& Brand Management, 19(5), pp.346-55.

Truong, Y., 2010. "Personal Aspirations and the Consumption of Luxury Goods". International Journal of Market Research, 52(5), pp.653-71.

Vigneron , F. \& Johnson, L.W., 1999. "A Review and a Conceptual Framework of Prestige-Seeking Consumer Behavior. Academy of Marketing Science Review .

Vigneron, F. \& Johnson, L., 2004. "Measuring perceptions of brand luxury". Journal of Brand Management, 11(6), pp.484-508.

Visser, R, 2015, "The relationship between status- and conspicuous consumption in luxury brands in the South African emerging market", Master thesis, University of Pretoria

Wiedmann, K.-P., Hennigs, N. \& Siebels, A., 2007. “Measuring consumers' luxury value perception: a crosscultural framework". Academy of Marketing Science Review, 7(7), pp.333-361.

Wiedmann, K.-P., Hennigs, N. \& Siebels, A., 2009. “Value-based segmentation of luxury of luxury consumption behavior". Psychology of Marketing, 26(7), pp.625-51.

Yoo, B. and Lee, S-H., 2009, "Buy genuine luxury fashion products or counterfeits?", Advances in Consumer Research, Vol. 36, pp. 280-306.

Yoo, B., Donthu, N. \& Lee, S., 2000. "An examination of selected marketing mix elements and brand equity". Journal of the Academy of Marketing Science, 28(2), pp.195-211.

Zaryouni, H., 2013. [Online] Available at: https://www.12inc.com/daily-insights/qatar-fastest-growingluxury-market [Accessed 23 November 2018].

Zeithaml, V., 1988. "Consumer perceptions of price, quality, and value: A means-end model and synthesis of evidence". Journal of Marketing, 52(3), pp.2-22. 